\title{
Economy and Social Development of Rural Sikkim
}

Sushmita Chakraborty ${ }^{\dagger *}$ and Namita Chakma ${ }^{i}$

\section{Abstract}

The tiny Himalayan state of Sikkim is well known for its multi-cultural and multi-ethnic identity. There is a political and historical debate regarding the identity of communities in Sikkim. Lepchas are considered as original inhabitants of Sikkim. Currently, Lepcha, Bhutia and Limbu are recognised as minor communities and have Schedule Tribes (ST) status in the state. Individual community concentration is mainly found in North and West Sikkim. Lepcha-Bhutias are found mainly in North Sikkim whereas Limbus are concentrated in West Sikkim. Community concentration is profound in rural areas. Gyalshing sub-division of West Sikkim has been selected for the present study. Purpose of this study is to investigate the Gram Panchayat Unit (GPU) level economy and social development of the rural areas based mainly on secondary sources of information. A field survey was also conducted to interact with the local people. Findings suggest that education and population density are the key determinants for GPU level disparity in social development of the study area. It has been found that the economy is primarily agriculture based and fully organised by organic farming system. Recently, homestay (eco)tourism business has been started here like other parts of Sikkim.

Key words: Himalaya, indigenous community, rural economy, organic farming, homestay (eco) tourism, social development, Sikkim, India

\footnotetext{
${ }^{\dagger}$ Research Scholar, Department of Geography, The University of Burdwan, Barddhaman, West Bengal, India, Email: sushmita.chakraborty8@gmail.com

${ }^{*}$ Corresponding Author

İ Assistant Professor, Department of Geography, The University of Burdwan, Barddhaman, West Bengal, India, E-mail: namitachakma@gmail.com

(C) 2016 Chakraborty and Chakma. This is an Open Access article distributed under the terms of the Creative Commons Attribution License (http://creativecommons.org/licenses/by/2.0), which permits unrestricted use, distribution, and reproduction in any medium, provided the original work is properly cited.
} 


\section{Introduction}

Until now very little is known about the socioeconomic development of rural Sikkim. Sikkim, which is an erstwhile Himalayan kingdom, became the 22nd state of Indian Republic in 1975. Because of its location and size (7096 sq. $\mathrm{km})$, this state has political and strategic significance (Chhetri, 2012). "Sikkim Himalayan region has a cultural complex, a composite of several cultural cosmoses rolled into one" (Bhasin, 2011, pp. 42). The mountain environment and remoteness has created a distinctive cultural heterogeneity in this tiny state. Indigenous communities include Lepcha, Bhutia and Limbu. Presently, Nepali community holds prime position in population size. They comprise $62.61 \%$ of the total population of Sikkim (Gazetteer of Sikkim, 2013). Out of the four districts, North and West districts are found to be more traditional due to their high rural concentration, typical cultural traits and way of life than other two districts (East and South).

"Ethnicity is identity with a group of people who share the cultural traditions of a particular homeland or hearth. An ethnic group is tied to a particular place because members of the groups or their ancestors were born and reside there" (Rubenstein, 2003, pp. 213). Seemingly, different communities of Sikkim are characterised by their individual culture, customs and tradition and they derived their identities from Jati Purana, ${ }^{1}$ ethnographic accounts and historical accounts constructed from time to time (Gazetteer of Sikkim, 2013). "Till 1982, few anthropological studies had been carried out in Sikkim after its integration in 1975 with India" (Bhasin, 2011, pp. 41). Lepcha, Bhutia and Limbu communities are considered as indigenous people of Sikkim (Gazetteer of Sikkim, 2013). From the Sikkim State Socio Economic Census, 2010, it is

\footnotetext{
${ }^{1}$ Jati Purana is a part of Vedic text literature of India. Jati means caste and purana means old literature. It denotes the pilgrim spots, status of caste hierarchy in South Asia, their profession, pride, etc. several ethnic communities and caste find their identity history from those old literature.
}

observed that, different ethnic communities form majority populace of some rural units (major Limbu-Tamang population in DarapNambu Gram Panchayet Unit is $63.47 \%$ and major Lepcha-Bhutia population in Tashiding GPU is $44.16 \%$ in whole sub-division). There are some rural areas, which are composed of mixed ethnic communities. All these communities are manifested by specific ecological adaptations. Ethnic groups have distinct cultural homogeneity and the habitable areas of them are separated from outside population, which make a barrier of cultural and social mixing (Bhasin, 2011). Actually, Lepchas are indigenous to Sikkim (Tamsang, 1983, Foning, 1987, Gowloog, 1995 cited in Arora, 2007 and Gazetteer of Sikkim, 2013). North Sikkim is mainly inhabited by Lepchas (Dzongu reserved area) (Dewan, 2012) and Bhutias (Lachen and Lachung areas). Limbu community is concentrated in the West district as per the State Socio Economic Census of Sikkim, (2010). Their proportion has been increased from $18.43 \%$ (Linguistic Survey of India, 2001) to $25.48 \%$ in 2010 . Every community has different religion, race, culture and social organization and wherever they found favourable physical and socio-economic condition, they started to settle in there.

Every human society has particular structure. Sociologists study the morphology of the society, but "a human society is not merely a collection of individuals arranged systematically into a set of groups and categories. It is also based on a set of norms and values, of modes of action which are considered right, proper and desirable" (Béteille, 1989, pp. 15). In case of rural West Sikkim, the character of the society is basically agrarian where agriculture is the major economic activity. It is quite obvious that, development is not same everywhere rather there exists disparity and inequality. Regional disparity is a worldwide phenomenon, which has spatio-temporal variation, and there exists an unequal distribution of social, economic and development parameters (Chakraborty and Chakma, 2015). It means divergence or inequality of characters, phenomena or process having specific 
territorial allocation and occurring at least two entities of the territorial structure (Kutscherauer, 2010). Taking into account this brief background, this research aims to examine the economy and social development of rural Sikkim with reference to the Gyalshing Sub-Division as a case study. The study begins with an introduction to the study area, followed by a rationale for selecting the study area. It then discusses the methods deployed for this research. In the final section, that is, in the results and discussion section, the results are analysed.

\section{The Study Area}

West district of Sikkim $\left(27^{\circ} 06^{\prime} 35^{\prime \prime} \mathrm{N}-27^{\circ} 35^{\prime} 5^{\prime \prime} \mathrm{N}\right.$ and $88^{\circ} 12^{\prime} 4^{\prime \prime E}-88^{\circ} 21^{\prime} 3^{\prime \prime E}$ ) covers 1166 sq. km area with a population density of 117 people/sq. km (Population Census of Sikkim, 2011). It is a part of lesser Himalaya consisting of Daling group of rocks, which overrides the Gondowana super group. The entire mountainous terrain of West Sikkim ranges from 300mt from (minimum elevation) Rangit river valley in south to $6706 \mathrm{mt}$ (maximum elevation) Pandim peak in north (Geology and mineral resources of Sikkim, 2012). West district consists of two subdivisions, that is, Gyalshing and Soreng. Gyalshing sub-division consists of 68 inhabited and 5 uninhabited villages, which form 26 GPUs with $94.40 \%$ rural population (highest) in West Sikkim. There are 117 villages in West Sikkim. Primary sector of economy in this sub-division comprises $59.98 \%$ cultivators, second highest after North District (73.70\%) and $36.13 \%$ of agricultural labours (highest in the whole of Sikkim, Census of India: Sikkim, 2011). Human Development Report of Sikkim 2014 stated that, livelihood of Sikkim is expanding mainly on the basis of tourism (focus upon the domestic tourism like-pilgrimage, culture, tradition, heritage, adventure, and ecotourism) and organic farming. Tourism becomes an important livelihood opportunity in Sikkim Tourism Mission 2015. Agriculture on the other hand, has started to move towards the industrial mode by producing organic products and it turns towards organic farming. Floriculture, food production (cardamom cultivation), fruit processing are becoming the viable mode of organic farming by using complete organic manure. Gyalshing subdivision is not outside this new mode of livelihood and therefore, it has become important to highlight these social and economic aspects.

\section{Rationale}

Study of economy and social development in rural areas is a highly relevant part in contemporary social sciences, which in turn could help the policy makers and planners for further development of the less developed areas. In similar contexts, this study was undertaken. This remote sub-division shares its international boundary with Nepal and therefore, has strategic significance. Gyalshing sub-division consists of highest rural units (68 villages in 2011) in the district. As the study focuses on the society and economy of rural West Sikkim, it is therefore justified to select this sub-division, which contains a high proportion of rural areas displaying a better rural scenario. The ethnic community concentration in this sub-division is also high. As per the report of Sikkim State Socio Economic Census, 2010, total Limbu-Tamang population in Gyalshing sub-division is 18955, higher than Soreng $(15,811)$ and in case of Bhutia and Lepcha, the total Bhutia-Lepcha population in Gyalshing sub-division is 14047 , higher than Soreng $(10,423)$. The administrative and political history of Sikkim started revolving around this sub-division from Yuksom, the prime capital of Sikkim protectorate to the second capital Rabdentsey (West Sikkim). So, this region comprises the earliest habitable area of indigenous community. Apart from this, as the study also focuses on the homestay tourism activity, it is found that the area has a good number of homestays operating well.

Thus, from the perspective of rural areas, highest ethnic community concentration, administrative and defensive centre of West Sikkim, historic-political background, village tourism accommodation system, it is justified to select this sub-division for research work to 
portray the socio-economic development of rural areas more precisely.

\section{Objectives}

The key objectives are as follows:

- To examine community concentration in the Gyalshing sub-division;

- To study the rural economy and;

- Finally, to examine the status of social development in the study area.

\section{Materials and Methods}

For this research, the data sources are based mainly on secondary sources of information, although field survey was conducted in 2015 for the purpose of reconnaissance verification. We had interviewed homestay owners (we use pseudonyms for these owners) to gain a deeper insight into their small businesses, which in turn might have helped rural Sikkim to attain economic growth. From the Gross State Domestic Product (GSDP) of Sikkim's economy, it is clear that from 2005-2014, Sikkim has highest average growth rate of GSDP (16.49\%) and share in Indian economy is $0.12 \%$ (Indian states by GDP, Statistics Time, 2015). Sector

$$
L Q i=\left(\frac{P i j}{P j}\right) /\left(\frac{P j}{P}\right)
$$

Where, $P i j=$ number of person in jth $(=1,2 \ldots \mathrm{m})$ category of area I $(=1,2 \ldots \mathrm{n})$

$P i=$ total population in all categories of area $\mathrm{I}, P j=$ sum of person category $\mathrm{j}$ in all the $\mathrm{n}$ areas, $P=$ total population of the region

By using Principal Component Analysis (PCA) and Factor Analysis, the research aims to examine the condition of social development of 26 GPUs in Gyalshing sub-division. PCA provides a "means of eliminating redundancies from a set of interrelated variables" (Sarkar, 2013, pp. 234) and Factor Analysis is essential because descriptive ideas of variables can summarise the relationships among the components of a system. Eigen values and Eigen vectors can be extracted, most diagnostic and significant variables in terms of factor loading can be identified and most importantly, the factor scores can be used as a criterion of differentiation between and among the samples in multivariate space (Sarkar, 2013) wise Gross Domestic Product (GDP) of 20122013 of Sikkim (Sector-wise GDP of Indian states, Statistics Time, 2014) shows that - it shares ?4430 million in agriculture and allied activities (focussing ?4080 million in only in agriculture), ?32340 million in industry, ?100 million in mining and quarrying, ?19660 million in manufacturing and ?18140 million in service sectors.

The data sources are Census of India (2011) published by the office of the Registrar General and Census Commission: New Delhi, Village Directory of West Sikkim 2011 from Census of India, Primary Census Abstract (PCA) 2011 of Sikkim from Census of India, Gazetteer of Sikkim (2013) and Sikkim State Socio-Economic Census (SSSEC), 2010.

Location Quotient (LQ) technique (Mahmood, 1988) has been applied to analyse the findings. LQ is an "index for comparing an area's share of a particular activity with the area's share of some basic or aggregate phenomenon" (Sarkar, 2013, pp. 207). Here, it has been used to examine the concentration of communities. [see Results and Discussion Part: iii for detail analysis]. PCA is computed by SPSS software version 14.0 (SPSS Inc., Chicago, Illinois, USA, 2009) and the figures are prepared by using Arc-GIS (version 9.3) software (Environmental Systems Research Institute, ESRI Developers Summit, 2008).

\section{Results and Discussion}

\section{Indigenous communities and their spatial} distribution in Gyalshing sub-division

There prevails political and historical debate regarding the identity of communities and relations among them in Sikkim (Bhasin 2002, Arora, 2006, 2007 and Sinha, 2008). 


\section{DOI: 10.20896/saci.v\%vi\%i.198}

Dastidar (2016) discusses the marginalised and minor tribes in Sikkim. She has highlighted that the state's environmental achievement when coupled with cultural differences of ethnic communities, it portrays the picture towards gender relations and the gender relations offer us a scenario of ethical politics in the domain of the Adivasis. Arora (2006) highlighted that, 'Lepcha-Bhutia ethnic alliance has historical, politico-economic, religious and cultural basis but the recent inclusion of the Limbu and Tamang in the scheduled tribes (ST) ${ }^{2}$ category in 2002, has evoked bitter opposition from the Lepchas and the Bhutias. Now, Limbus and Tamangs demand political reservations in the Constitution, similar to that of the Bhutias and Lepchas. To provide the privilege of Limbu and Tamang communities, Sikkim government has proposed to the central government that the strength of the state legislative assembly should be increased from 32-40 (Arora, 2006). To investigate the spatial concentration pattern of community distribution, we relied on the Sikkim State Socio Economic Census (2010) report. They have categorised and represented data by taking Limbu and Tamang communities together and Bhutia-Lepcha communities together. Bhutia-Lepcha community has Buddhist religious alliance and hold 12 seats in assembly ever since the first election of Sikkim (Chakraborty 2000, Kharga and Bhutia, 2015). Limbu-Tamang communities are now enumerated officially within the Nepali population (Census of India 2001 cited in Arora, 2006) but they demanded for separate ST status and separate assembly seats from the year 2000 but until now the debate of seat reservations for Limbu-Tamang communities continues.

\footnotetext{
2 Scheduled Tribes are the constitutional designation given to various groups who are historically in disadvantaged and indigenous to India. "Article 366 (25) refers to schedule tribes as those communities who are scheduled in accordance with article 342 of the constitution. According to article 342 of the constitution, the schedule tribes are the tribes or tribal communities or part of or groups within this tribes and tribal communities which have been declared as such by the President through a public notification" (Ministry of Tribal Affair, Government of India, 2016).
}

We have used Location quotient technique to examine the spatial concentration pattern of the stated communities (Figures 1 and 2). It has been found that both the communities are concentrated in a similar way though their distribution pattern is different. Gini coefficient values for Bhutia-Lepcha communities is found to be $17.63 \%$ whereas, for LimbuTamang communities, it is $20.15 \%$. The values unveil that the overall community concentration is less in the region.

Spatial distribution pattern shows that LimbuTamang communities are concentrated in seven GPUs $(L Q>1)$ whereas, Bhutia-Lepcha communities are concentrated in 12 GPUs $(L Q>1)$. High Limbu-Tamang dominated areas are found in Darap-Nambu, ManeybungSopakha and Hee areas. Darap village in DarapNambu GPU has scored highest in terms of Limbu-Tamang population in the sub-division (80.82\%). On the other hand, Bhutia-Lepcha communities are highly concentrated in Tashiding, Singyang-Chongpong, Dentam and Sanghu-Radhukundu areas. Mangthyang village in Tashiding GPU is the major Bhutia-Lepcha dominated village (75.40\%) in the whole subdivision.

There are several facts behind the concentration of particular community in particular areas. For examples, Limbu and Tamang communities are good cultivators and therefore, used to settle in the riverside fertile areas whereas, hilly terrain, which is free from flood, is always the most preferable place of habitation of the Bhutias and the Lepchas (Bhasin, 2011). In the study area, farming is mainly dominated by mountain agriculture on small landholdings in the slopes and on terraces in the hills. Surrounding forests are sometimes used for grazing cattle and collection of fodder, firewood, medicinal and aromatic herbs. 


\section{Gyalshing Sub Division \\ GPU wise concentration of Limbu-Tamang community}

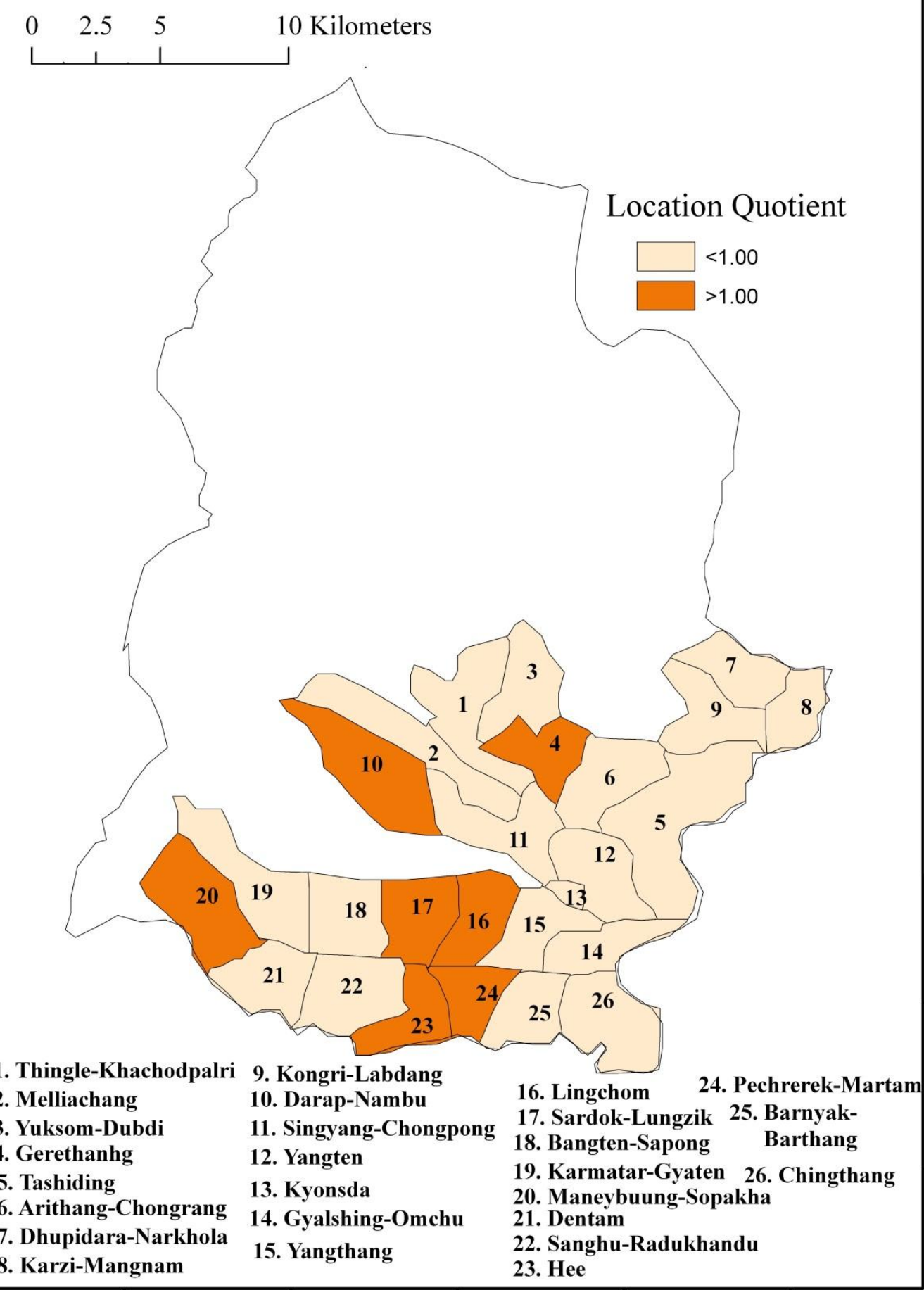

Figure: 1, Source: Based on Sikkim State Socio-Economic Census, 2010, Courtesy: Authors 


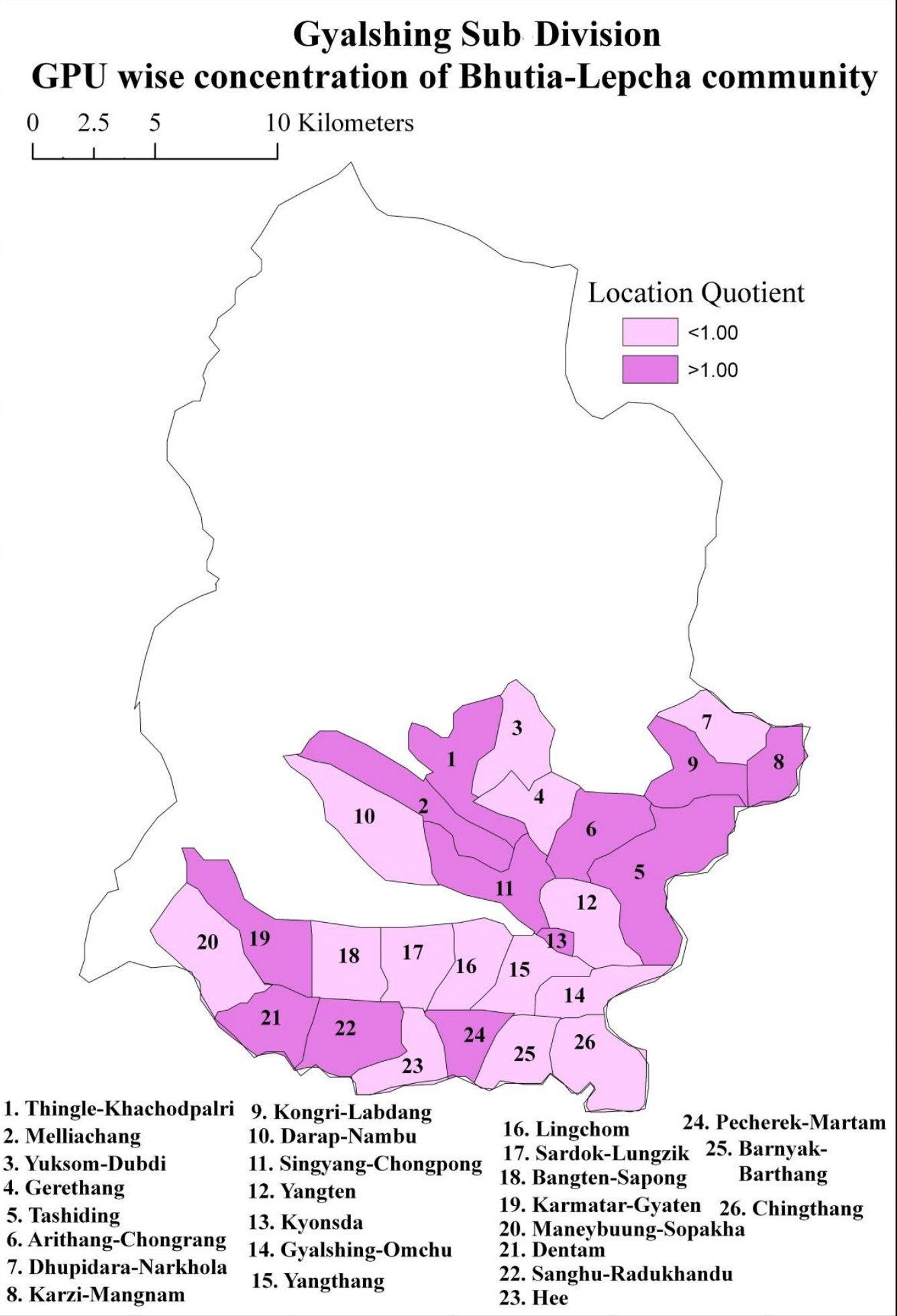

Figure: 2, Source: Based on Sikkim State Socio-Economic Census, 2010, Courtesy: Authors

\section{Rural Economy}

There is keen relation among rural economic diversification and environment in the study area. Environment include the forest, land, vegetation assets which are utilised directly or indirectly to provide means of survival of the human population. The rural areas of Gyalshing sub-division support interesting and diversified economic system, which includes agriculture (organic farming) and homestay tourism (ecotourism). 


\section{Agriculture}

In agriculture, the land is the fundamental asset whereas land tenure, labour input, land productivity, physical settings, productionsurplus of the products; and markets are the determinants of whole production system. Chakraborti (2010) observed that the land reform and traditional agrarian structure of Sikkim are changing from time to time. At the time of monarchy (Namgyal Dynasty) there prevailed a feudal agrarian system and the migrant Nepalese had no land right, but the situation switched over after 1975 when the government took initiative to abolish the intermediaries with the introduction of the Sikkim Cultivators Protection Act (1975), the Sikkim Agricultural Land Ceiling and Reforms Act (1978), and the Sikkim Land Requisition and Acquisition Act 1978. As a result, the total food grain production in the state has registered a healthy increase in absolute terms. Now the scenario has turned towards new arena when the Prime Minister Mr. Narendra Modi (in 2016) has declared Sikkim as the first fully organic state in India and agricultural products are purely organic. Thus, the continuous changing land regulation system not only enhances the new horizon in the field of agriculture, it also improves the rural economy and the livelihood opportunities of the people.

In the study area, the farming is mainly dominated by mountain agriculture on small landholdings in the slopes and on terraces in the hills. The challenge in this region is to produce enough food to maintain a family on a relatively small plot. Decreasing drinking water and water for irrigation purpose become a matter of huge concern among locals. Due to climate change the glaciers that feed the rivers of Sikkim have started to retreat faster than recorded earlier and small springs in the mountains are starting to dry up portending more uncertain water availability in the future (Tambe et al., 2011).
Currently cardamom is the main cash crop in the area. Apart from cardamom, the other important crops are maize, paddy, ginger, wheat, etc. Census of India, 2011 shows that, maize, cardamom and paddy are the first important agricultural commodities in the rural areas of this sub-division (Table 1). Total net shown area in Gyalshing sub-division is 13742.46 hectares and the major portion is unirrigated land (Figure 3). Water use in agriculture is mainly obtained from the local jhoras (springs) in villages and directly from river. However in most areas of the villages, piped water supply in the agricultural field from jhoras are common.

Organic farming includes crop rotation, green manure, compost, and biological pest control. Sikkim set the goal to achieve the status of fully organic state within 2015 (Chhetri, 2013) and when it is achieved, it becomes the first organic and greenest state in whole India. This farming technique has the potentiality to provide the benefits in terms of environmental protection, non-renewable resource conservation and improved food quality and in this process, chemical fertilisers and pesticides or any other kind of chemical inputs be avoided. Chemicals are replaced by organic inputs and organic sources of soil nutrients. The mountainous state like Sikkim and other North-Eastern states where agriculture system is generally rain fed, the chemical use did not have significant impact on production and productivity of the crops. This efficient organic farming makes farmers successful to maintain the food security for their families because food productions require low cost and low external inputs (Chhetri, 2015). Farmers have become economically independent in the years after the transition of agriculture to organic farming. There is not much loan on the farmer's side (Provisional Results of Economic Census, 2005) [see also Figure 4]. 


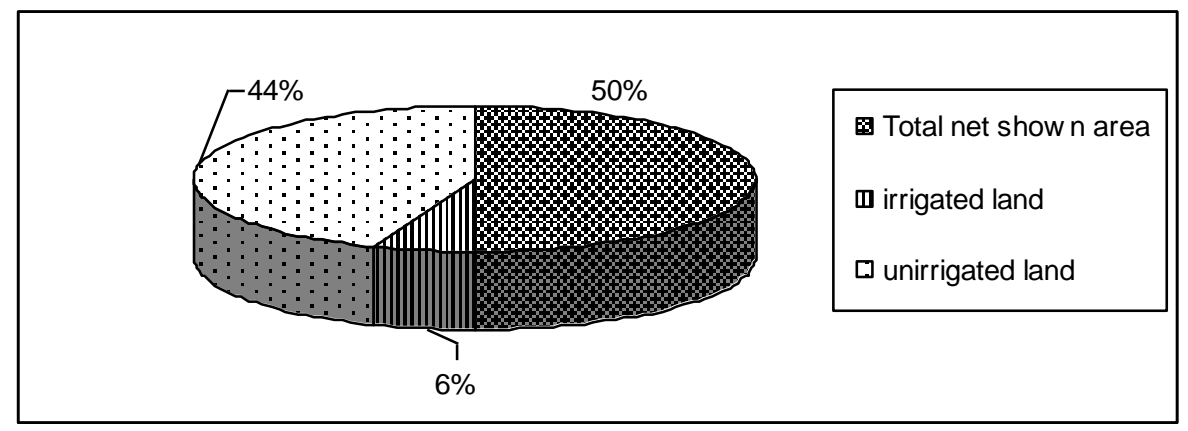

Figure: 3- Total irrigation scenario of Gyalshing sub-division; Source: Office of the Registrar General and Census Commissioner, India, Ministry of Home Affairs, Government of India. Retrieved from, at: http://censusindia.gov.in (accessed August 21, 2014)

\begin{tabular}{|c|c|c|c|}
\hline Name of GPUs & $\begin{array}{l}\text { First agriculture } \\
\text { commodities }\end{array}$ & $\begin{array}{l}\text { Second agriculture } \\
\text { commodities }\end{array}$ & Third agriculture commodities \\
\hline Yuksom-Dubdi & Potato, Millets & Millet, Potato & Maize \\
\hline Gerethang & Cardamom, Maize & Ginger, Paddy & Paddy, Vegetables \\
\hline Tingle-Khachodpalri & Maize & Cardamom, Millet & Millet, Barley, Cardamom \\
\hline Melliaching & Maize, Millet & Millet, Ginger & Ginger, Maize, Vegetables \\
\hline Darap-Nambu & Maize, Cardamom & Millet & Vegetables, Maize, Paddy \\
\hline Singyang Chongpong & Paddy, Maize, Vegetables & Millet, Cardamom & $\begin{array}{l}\text { Vegetable, Paddy, Maize, } \\
\text { Ginger }\end{array}$ \\
\hline Yangten & Maize & Paddy, Millet & Millet, Paddy \\
\hline Arithang Chongrang & Maize & Millet & Paddy \\
\hline Kongri Labdang & Cardamom, Maize & Maize, Vegetables & Millet, Ginger \\
\hline Dhupidara Narkhola & Cardamom, Maize & Cardamom, Maize & Millet \\
\hline Karzi Mangnam & Cardamom & Maize & Millet \\
\hline Tashiding & Cardamom, Maize & Maize, Paddy, Pulses & Millet, Pulses \\
\hline Gyalshing Omchu & Maize & Paddy & Millet \\
\hline Yangthang & Maize & Paddy, Millet & Millet, Paddy \\
\hline Lingchom Tikjya & Paddy & Millet, Maize & Maize, Millet \\
\hline Sardong Lungzik & Maize & Millet, Paddy & Paddy, Wheat \\
\hline Bangten Sapong & Maize & Millet & Paddy \\
\hline Karmatar Gyaten & Maize & Millet, Paddy & Paddy, Wheat \\
\hline Maneybung Sopakha & Maize & Wheat, Millet & Paddy \\
\hline Dentam & Paddy, Maize & Paddy, Maize & Wheat \\
\hline Sangkhu Radukhandu & Maize & Cardamom & Paddy \\
\hline Hee & Wheat & Maize & Paddy \\
\hline Kyonsda & Cardamom, Maize & Maize, Millet & Paddy \\
\hline Pecherek -Martam & Paddy, Maize & Paddy & Millet \\
\hline Barnyak Barthang & Maize & Maize, Paddy & Millet \\
\hline Chingthang & Paddy, Maize & Maize, Ginger & Millet \\
\hline
\end{tabular}

Source: Census of India: 2011, Office of the Registrar General and Census Commissioner, India, Ministry of Home Affairs, Government of India. Retrieved from, http://censusindia.gov.in (accessed August 25, 2014) 


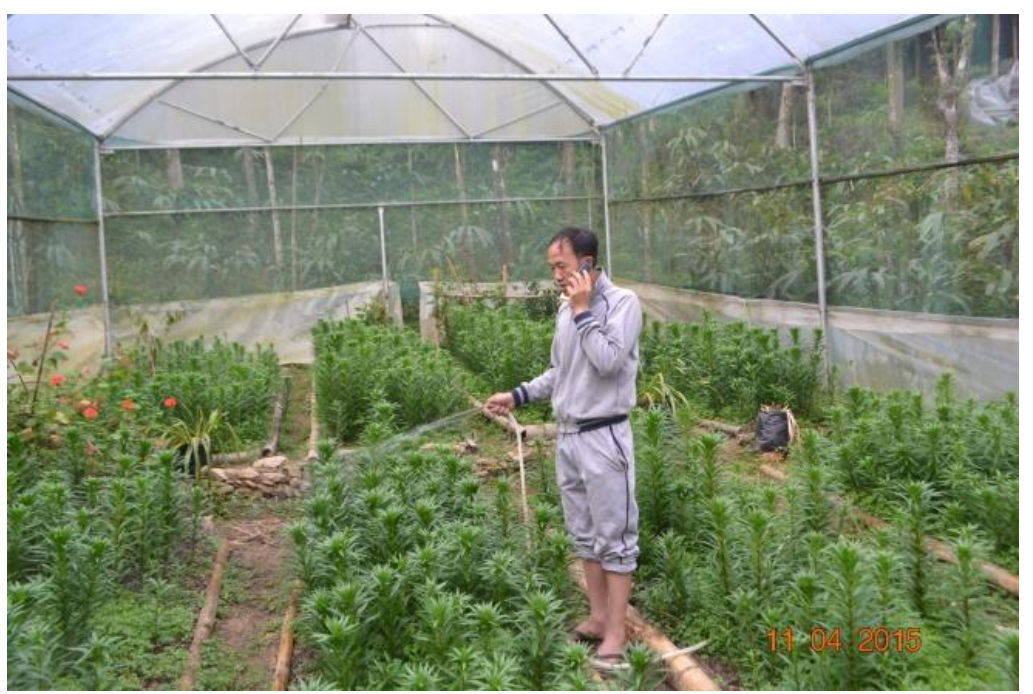

Figure: 4 - Floriculture in a Green House, Darap village, Source: Field Survey, April 2015

\section{Homestay}

Tourism, including both ecological and cultural attributes, is increasingly prevalent around the world (Hendry, 2005 and Richards, 2007). Eco tourism is a part of eco-cultural tourism. It is synergy of prevalent local culture and sustainable form of natural resource based tourism (Fennell, 1999). Homestay tourism emerges as a substitute livelihood opportunity in the whole of Sikkim as well as in the Gyalshing sub-division. There are 14 homestays in the sub-division and most of the homestays have been developed in Darap-Nambu GPU. This GPU is just $10 \mathrm{~km}$ away from well-known tourist destination Pelling (famous point for viewing Mt. Kangchenjunga) in West Sikkim (see Table-2).

To have an idea we directly contacted the homestay (similar to bread and breakfast in the UK but more in terms of food and entertainment) owners during our visit to the area at April 2015. The survey occurred in community based homestays in Darap-Nambu GPU and different communities (Limbu, Lepcha, Bhutia and Tamang) are found to be involved in homestay tourism business. The guests of the homestays are served with traditional cuisine, drinks, and they are entertained by traditional song and dances of the representative communities. The observations are as follows:

- Homestays are operated mainly along the Pelling-Yuksom road (only metallic road in the sub-division).
- Change in social behaviour of the communities has helped to participate in the cultural exchange programme through homestays. People wish to earn more have opened up their doors to the outside world.

- All the family members (including female) are taking the charge of hospitality of the guests (tourists). They welcome the guests, cook traditional dishes for them and serve with pleasure. They play the role of local guide also.

- Home stay development requires a huge amount of money at the initial stage. Non-government organisations (NGOs) and schemes (credit guarantee fund trust for micro and small enterprises) of Sikkim government paved the way by providing financial support to the local people.

The emerging business has economic and social impacts on the communities.

First, a wide range of employment opportunities are being generated with a regular flow of earning, thereby, improving the standard of living and the levels of income. The idea of developing the village, as an offbeat destination for tourists in the form of ecocultural tourism, has changed the lifestyle of the local people. These accommodations serve interaction opportunities to the tourists with local communities and the tourists in turn take back the flavour of traditional cultural heritage 
of the communities. Income generation and share of traditional culture are the results of homestay tourism.

During a survey in Darap, we talked with the owner of Sukhim homestay, Prema Chhetri (aged 24). In her words:

My husband and my father-in-law invested money to start the home stay business and an NGO named Pragya funded it. We started the home stay seven years ago. My husband is engaged in agricultural activities and marketing business. Previously my husband was a local trekking guide and when he met several tourists during trekking, the inspiration came from the tourists to start home stay. We got training in cooking from Cherry Village
Home stay in Darap. The available facilities are traditional food, leisure work etc. which cherish the tourists. The rent of the homestay varies according to the season and food option.

Another homestay owner Hemant Kumar Subba (aged 32 of SO?BU homestay, means friendship in Limbu language) stated that:

We started the business as a substitute of income generation apart from farming. Our family members are engaged in different occupation and every family member especially females of the household are engaged in this work. We want to share the traditional Limbu cultural traits with the tourists [see also Figures 5 and 6].

Table 2: Homestay Accommodation in Gyalshing Sub-Division, West Sikkim, 2016

\begin{tabular}{ll} 
Name of the Homestay & Place \\
\hline So? Bu & Darap \\
\hline Norbulinka Retreat & Yangten \\
\hline Barsey Jungle Camp & Hee Patal, Near Red Panda Gate \\
\hline Lake View Nest & Khachodpalri \\
\hline Chuden & Maneybung \\
\hline Yuksom & Yuksom \\
\hline Sukhim & Darap \\
\hline The Last Resort & Hee Gaon \\
\hline Martam House & Tikjuk \\
\hline Samikla & Maneybung \\
\hline Hitaishi & Bermiok, Martam \\
\hline Muringla Villa & Lingchom \\
\hline Daragaon Village Retreat & Darap \\
\hline Serworo & Darap
\end{tabular}

Source: Sikkim, Ministry of Tourism, Government of Sikkim, 2016

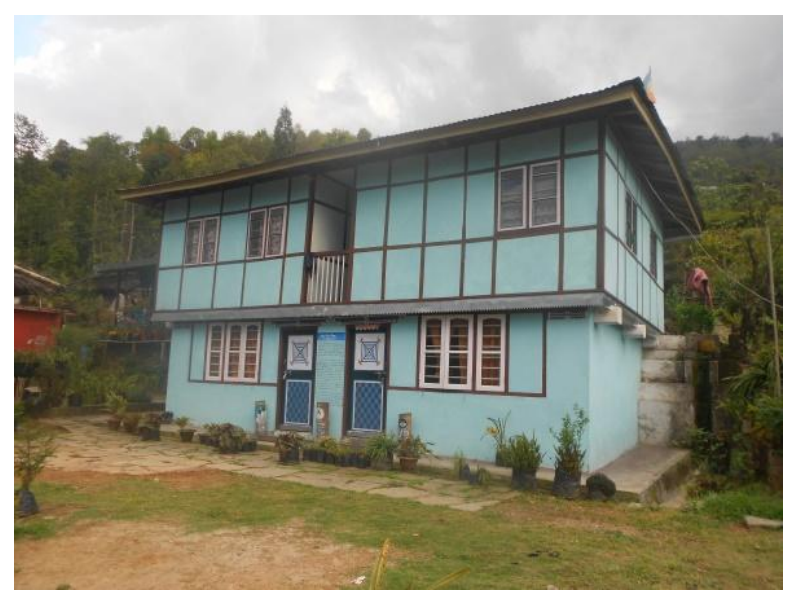

Figure: 5- 'So? Bu' Homestay in Darap village, Source: Field survey, April 2015 


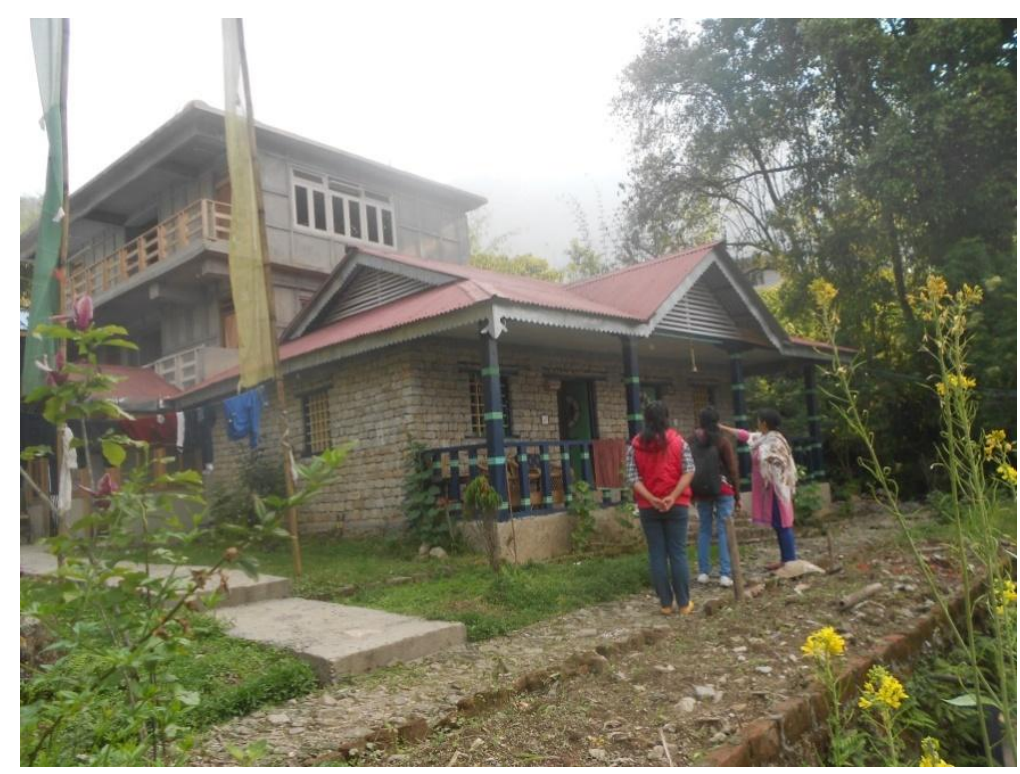

Figure: 6- Daragaon Village Retreat Homestay in Darap village, Source: Field Survey, April 2015

Spatial Disparity in Social Development of GPUs of Gyalshing Sub-Division

Spatial disparity in social development has been analysed on the basis of selected social parameters using Census of India, 2011 data. These are: population density, percentage of literacy, percentage of female literacy, percentage of workers to total population, percentage of female workers to total workers, number of government schools (includes all primary, secondary and senior secondary schools), number of private schools (includes all primary, secondary and senior secondary schools), number of primary health centres and dispensaries, location of drinking water within premises and availability of assets (includes radio/transistor, television, computer/laptops, telephone/mobile phone, bicycle, scooter/motor cycle/moped, car/jeep/van, households with TV, computer/laptop).

A multivariate analysis seems to be necessary to find out the relative importance of each variable. The correlation matrix and PCA are the standard devices in this study. From the correlation matrix (Table 3 ), the nature of bivariate relationship of number of variables has been found. The principal component analysis provides the basis of sorting out a number of few components, which account for the major amount of explained variation of the selected variables and rest of the component has negligible importance. First, seven factors have been extracted from major 10 factors through
PCA. Then through factor analysis, it is found that (Table 4), selected variables have extracted $34.96 \%$ in first PCA, in the second stage, $55.42 \%$ is explained and finally, in the third stage $71.61 \%$ have been explained. After the analysis, it is observed that number of government schools, total literacy rates and population density become the guiding variables and play crucial positive roles in the study of social status. On the other hand, percentages of female literacy, percentages of total workers, and percentages of female workers and location of drinking water within premises are less significant factors in terms of social development because people from village areas have less willingness to send their girl child to the outside of the district. Only one government college is located in Geyzing (Gyalshing) town. Females are mostly engaged in household works, agriculture fields, and fuel woods collection and as workers in different self-help groups (SHG). Thus, women education has lesser significance in social development in the study area. Location of drinking water within premises has also least significance because villagers obtained drinking water from the nearby jhoras (springs). In the village areas, there is no water borne diseases reported in primary health centres and dispensaries. Thus, education infrastructures with total literacy rates of the people from all age groups are found to be good to drive the social development. High population density in some 
places demands more education infrastructures and education development programmes, which results the development of those places.

The level of development has also been assessed in spatial context through mapping with prince score values extracted from Principal Component Analysis on the basis of same social parameters, which have been chosen for the present context of study (Figures 7, 8 and 9). After calculating the Prince Score values, it is found that, the overall social condition is not well in these GPUs. Only two GPUs namely, Arithang-Chongrang and SanghuRadukhandu are socially developed and BhutiaLepcha communities are being concentrated there. Whereas, Tashiding, Karmatar-Gyaten and Dentam are found to be in less developed condition and are again dominated by the Bhutia-Lepcha communities. Therefore, we can conclude that community concentration does not have any direct relation with the social development of the GPUs.

Table 3: Pearson's Product Moment Correlation Matrix of Variables, Gyalshing Sub-Division, 2011

\begin{tabular}{|c|c|c|c|c|c|c|c|c|c|c|}
\hline Variables & A & B & C & D & $E$ & $\mathbf{F}$ & $\mathbf{G}$ & H & I & $\mathrm{J}$ \\
\hline$A$ & 1.00 & 0.34 & 0.12 & -0.41 & 0.06 & -0.25 & 0.22 & -0.03 & 0.03 & 0.03 \\
\hline$B$ & & 1.00 & -0.39 & -0.23 & -0.04 & 0.42 & 0.39 & 0.17 & 0.16 & 0.09 \\
\hline $\mathrm{C}$ & & & 1.00 & -0.34 & 0.24 & -0.26 & -0.31 & -0.19 & 0.17 & -0.18 \\
\hline $\mathrm{D}$ & & & & 1.00 & 0.11 & 0.12 & 0.21 & 0.33 & -0.04 & 0.39 \\
\hline$E$ & & & & & 1.00 & 0.02 & 0.08 & 0.29 & 0.32 & 0.44 \\
\hline $\mathrm{F}$ & & & & & & 1.00 & 0.33 & 0.57 & 0.10 & 0.29 \\
\hline G & & & & & & & 1.00 & 0.27 & -0.10 & 0.32 \\
\hline $\mathrm{H}$ & & & & & & & & 1.00 & 0.12 & 0.37 \\
\hline 1 & & & & & & & & & 1.00 & 0.09 \\
\hline $\mathrm{J}$ & & & & & & & & & & 1.00 \\
\hline
\end{tabular}

Note: $A=$ population density, $B=$ percentage of literacy, $C=$ percentage of female literacy, $D=$ percentage of workers to total population, $E=$ percentage of female workers to total worker, $F=$ number of government schools, $\mathbf{G}=$ number of private schools, $\mathrm{H}=$ number of health centres and dispensaries, l= location of drinking water within premises, $\mathrm{J}=$ availability of assets) Source: Computed by the Authors

Table 4: Component Matrix of Factor Analysis (Extraction Method-PCA) of Variables, Gyalshing Sub-Division, 2011

\begin{tabular}{llllllll} 
Variables & A & B & E & F & G & H & J \\
\hline PC1 (34.96\%) & 0.23 & 0.56 & 0.38 & 0.74 & 0.66 & 0.72 & 0.64 \\
\hline PC2 (55.42\%) & 0.56 & 0.63 & -0.58 & 0.06 & 0.28 & -0.30 & -0.43 \\
\hline PC3 (71.61\%) & 0.64 & -0.02 & 0.54 & -0.51 & 0.10 & -0.29 & 0.26 \\
\hline \multicolumn{7}{c}{ Initial Eigen $=2.44$} \\
\hline
\end{tabular}

Source: Computed by the Authors 


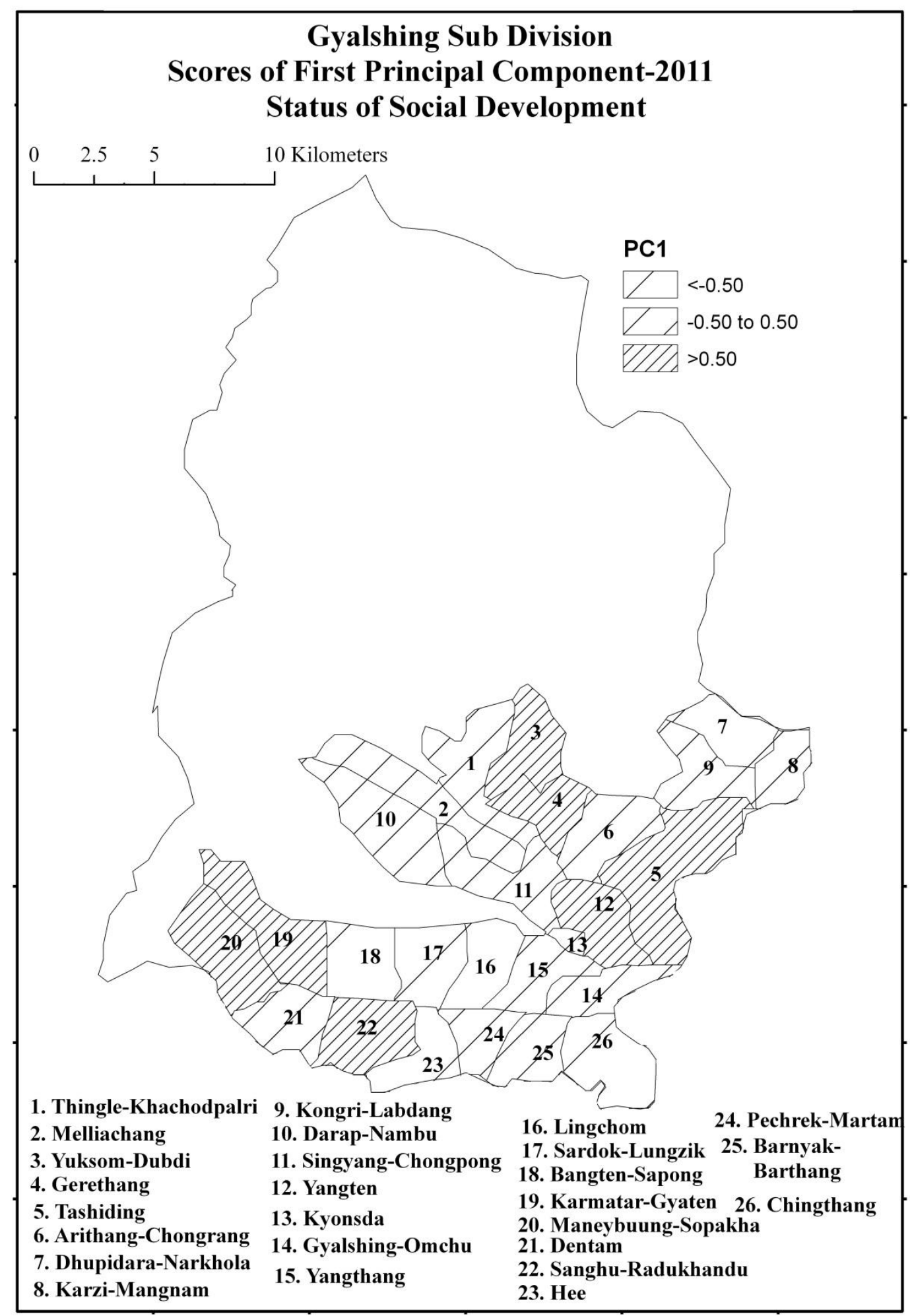

Figure: 7, Source: Ministry of Home Affairs, Government of India. Retrieved from, http://censusindia.gov.in, Courtesy: Authors 


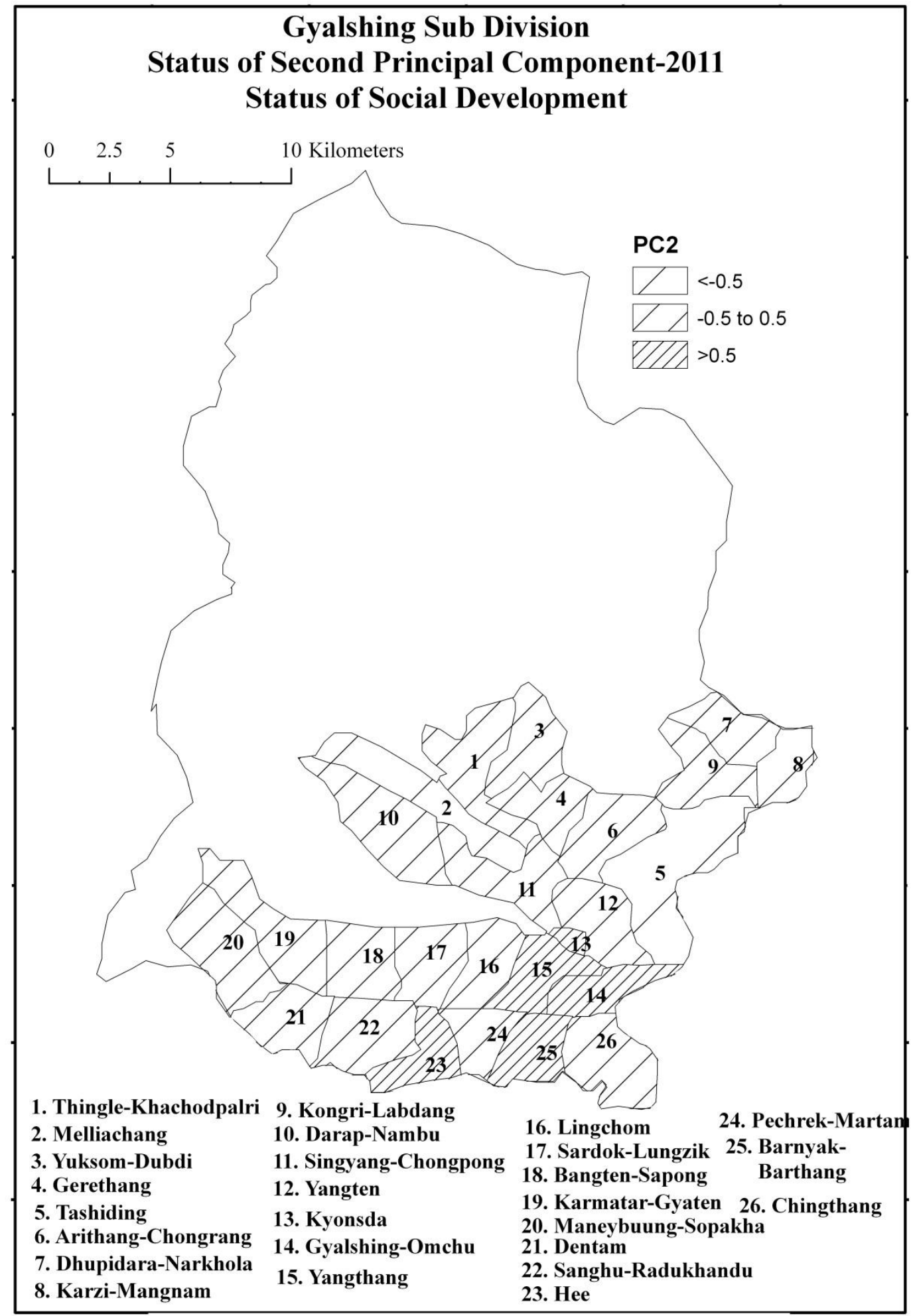

Figure: 8, Source: Ministry of Home Affairs, Government of India. Retrieved from, http://censusindia.gov.in, Courtesy: Authors 


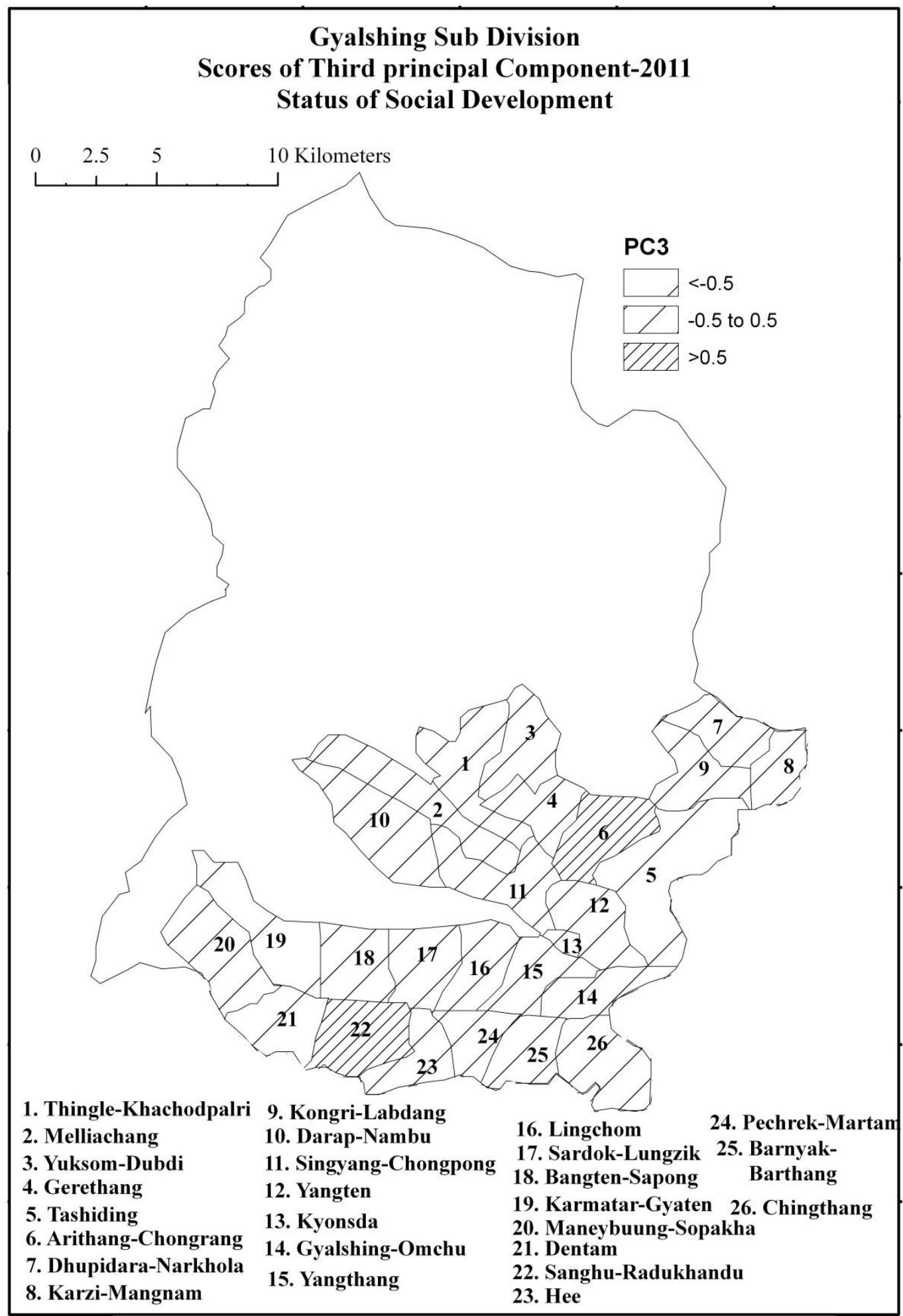

Figure: 9, Source: Ministry of Home Affairs, Government of India. Retrieved from, http://censusindia.gov.in, Courtesy: Authors

\section{Conclusion}

Different aspects of the rural society and economy of Gyalshing sub-division, West Sikkim has been discussed in the study. Communities have their spatial concentration in the villages. The rural economy is mainly based on agriculture and homestay tourism. Presently, homestay tourism adds additional economic opportunity to the villagers. This arrangement 
has twin benefits as tourists are gaining opportunity to interact with the local communities, in this way, learning the flavours of cultural heritage and natural environment whereas, local communities are accessing the opportunities to regenerate their culture and to earn more. Social interactions have a chance of cultural mixing and it may harm the long and traditional cultural heritage of the communities. The educated youths are aware of this fact but according to them, they are considering the positive aspects only as the homestay business has no perceptible negative social environmental impact right now. As education facilities and population densities are not same everywhere, therefore, inter GPUlevel disparity in social development has profound in the analysis. However, further indepth research is required for better understanding of the region and its people.

\section{References}

Arora, V. (2006, September 23-29). Routes and the Route of Secularism in Sikkim. Economic and Political Weekly, 41(38), 4063-4071. Retrieved June 28, 2016, from http://www.jstor.org/stable/4418729

Arora, V. (2007, Fall). Assertive Identities, Indigeneity, and the Politics of Recognition as a Tribe: The Bhutias, the Lepchas and the Limbus of Sikkim. Sociological Bulletin, 56(2), 195-220. Retrieved June 28, 2016, from http://www.academia.edu/3353268/As sertive_identities_indigeneity_and_the politics_of_recognition_as_a_tribe_The _Bhutias_the_Lepchas_and_the_Limbus _of_Sikkim

Arora, V. (2007, August 25). Unheard Voices of Protest in Sikkim. Economic and Political Weekly, 3451-3454. Retrieved June 28, 2016, from www.epw.in/system/files/pdf/2016_51/ 25/Marginalised_as_Minority_0.pd.

Beteille, A. (1989). Inequality and Social Change (7th ed.). Delhi, Delhi: Oxford University Press.
Bhasin, V. (2002). Ethnic Relations among the People of Sikkim. Journal of Social Science, 6(1), 1-20. Retrieved June 29, 2016, from http://www.krepublishers.com/02Journals/JSS/JSS-06-0-000-000-2002Web/JSS-06-1-001-02-Abst-PDF/JSS-061-001-02-Bhasin-V/JSS-06-1-001-02Bhasin-V-Tt.pdf

Bhasin, V. (2011). Settlement and Land-Use Patterns in the Lepcha Reserve-Dzongu Zone in the Sikkim Himalaya, India. Journal of Biodiversity, 2(1), 41-66. Retrieved June 29, 2016, from http://www.krepublishers.com/02Journals/JBD/JBD-02-0-000-11Web/JBD-02-1-000-11-Abst-PDF/JBD02-1-041-11-017-Bhasin-V/JBD-02-1041-11-017-Bhasin-V-Tt.pdf

Census of India, 2001. (2001). New Delhi: Office of the Registrar General \& Census Commissioner, India, Ministry of Home Affairs, Govt. of India. Retrieved August 21, 2014, from http://censusindia.gov.in

Census of India, 2011. (2011). New Delhi: Office of the Registrar General \& Census Commissioner, India, Ministry of Home Affairs, Govt. of India. Retrieved August 25, 2014, from http://censusindia.gov.in

Chakraborty, J. (2000). Election and Castiest Politics. Economic and Political Weekly. Retrieved May 16, 2016, from http://www.jstor.org/stable/4418729

Chakraborti, A. (2010, January 30). A Critical Review of Agrarian Reforms in Sikkim. Economic and Political Weekly, 45(5), 23-26. Retrieved June 11, 2016, from www.epw.in

Chakraborty, S., \& Chakma, N. (2015). Assessment of Regional Disparity of Sikkim in the Course of Social Development. In Applications of Geospatial Technology for Sustainable Develpment (pp. 257-265). New Jalpaiguri, West Bengal: University of North Bengal. 
Chhetri, D. P. (2012). Decentralised Governance and Development in India, With Special Reference to Sikkim (1st ed.). New Delhi: Mittal Publication.

Chhetri, D. P. (2013). MGNREGS in Sikkim Himalaya - A Catalyst for Women Economic Empowerment and Livelihood Security. Labour \& Development, 20(2). Retrieved May 18, 2016, from http://www.vvgnli.org/sites/default/file s/publication_files/Labour-Development

Chhetri, M. (2015). Empowering Farmers through Organic Farming in the Himalayan State of Sikkim. American International Journal of Research in Humanities, Arts and Social Sciences. Retrieved May 2, 2016, from http://www.iasir.net

Dastidar, M. (2016). Marginalised as Minority: Tribal Citizens and Border Thinking in India. Economic and Political Weekly, 48-54. Retrieved June 28, 2016, from www.epw.in/system/files/pdf/2016_51/ 25/Marginalised_as_Minority_0.pd

Dewan, D. B. (2012). Education in Sikkim: An Historical Retrospect, Pre-Merger and Post-Merger Period (1st ed.). Kalimpong, West Bengal: Society for the Procurement and Sales of Books.

Fennel, D. (1999). Ecotourism: An Introduction. London: Routledge.

Foning, A. R. (1987). Lepcha: My Vanishing Tribe. Delhi: Sterling.

Geology and Mineral Resources of Sikkim (29Sikkim, pp. 1-54, Rep. No. 30,) (P. Dey, B. C. Roy, K. V. Nambiar, \& I. K. Khan, Eds.). (2012). Director Generel, GSI, Government of India. Retrieved November 21, 2015, from http://www.indiawaterportal.org/sites

Gowloog, R. R. (1995). Lingthem Revisited: Social Changes in a Lepcha Village of North Sikkim. New Delhi: Har Anand.

Hendry, J. (2005). Reclaiming Culture: Indigenous People and Self-
Representations. Retrieved January 13, 2016, from www.palgraveconnect.com

Kharel, S., \& Bhutia, J. W. (Eds.). (2013).

Gazetteer of Sikkim (1st ed.). Gangtok, Sikkim: Home Department, Government of Sikkim.

Indian States by GDP. (2015, August 20). Retrieved September 16, 2016, from http://statisticstimes.com/economy/gd p-of-indian-states.php

Kharga, M., \& Bhutia, R. T. (2015). Democratic Associations and Political Representation of Tribal Population in Sikkim: A Study of the Associational Activity of Bhutias and Lepchas. International Journal of Scientific and Research Publications, 5(6). Retrieved July 11, 2015, from http://www.ijsrp.org

Kutscherauer, A. (2010). Regional Disparities, Disparities in Country Regional Development Concept, Theory, Identification and Assessment. Ostrava: VŠB-Technical University of Ostrava, Faculty of Economics. Retrieved September 10, 2014, from http://disparity.idealnihosting.cz/edice_ cd/cd11_regdis_mono_angl/pdf/Region al disparities.pdf

Linguistic Survey of India Sikkim, Part I. (2001). New Delhi: Office of the Registrar General \& Census Commissioner, India, Ministry of Home Affairs, Govt. of India. Retrieved July 10, 2014, from http://censusindia.gov.in

Mahmood, A. (1988). Statistical Method in Geographical Studies (Vol. 1). Kolkata, West Bengal: Pan Publishing Company.

Ministry of Tribal Affairs. (2016). Retrieved September 15, 2016, from http://tribal.nic.in/

Provisional Results of Economic Census 2005 (pp. 1-33, Rep. No. 5). (2005). New Delhi: Ministry of Statistics and Programme Implementation, Government of India. Retrieved May 26, 2016, from http://www.mospi.gov.in 
Richard, G. (Ed.). (2011). Cultural Tourism: Global and Local Perspective (5th ed.). Retrieved May 30, 2016, from http://samples.sainsburysebooks.co.uk/ 9781136792342_sample_683449.pdf

Rubenstein, J. M. (2003). The Cultural Landscape: An Introduction to Human Geography. New, Jersey United States of America: Pearson Education.

Sarkar, A. (2013). Quantitative Geography: Techniques and Presentations. New Delhi: Orient Blackswan Private Limited.

Sector-wise GDP of Indian states. (2014, December 14). Retrieved September 16, 2016, from http://statisticstimes.com/economy/sec torwise-gdp-of-indian-states.php

Sikkim Human Development Report: Expanding Opportunity Promoting Sustainability (Rep.). (2014). New Delhi: Routledge. Retrieved October 16, 2015, from https://www.sikkim.gov.in/stateportal/L ink/Sikkim Human Developent Report 2014.pdf.

Sikkim State Socio Economic Census [EXCEL]. (2010). Tikjuk, West Sikkim: Department of Economics, Statistics, Monitoring and Evaluation, Government of Sikkim.

Sikkim, Ministry of Tourism. (2016). Retrieved May 31, 2016, from http://www.tourism.gov.in/state/sikkim

Sinha, A. C. (2008). Sikkim: Feudal and Democratic. New Delhi: Indus Publishing Company.

Tambe, S., \& Arrawatia, M. L. (2011, July 25). Rapid, Cost-Effective and High
Resolution Assessment of Climate-

Related Vulnerability of Rural

Communities of Sikkim Himalaya, India.

Current Science, 101(2). Retrieved

February 21, 2016, from

http://www.sikkimforest.gov.in/climate -change-in-sikkim/15-Chapter-

Rapid,Cost Effective and High Resolution Assessment of Climate.pdf

Tamsang, K. P. (1983). 2. In The Unknown and Untold Reality about the Lepchas. Retrieved May 21, 2016, from

http://shodhganga.inflibnet.ac.in/bitstream/10 603/18474/8/08_chapter 2.pdf.

\section{Acknowledgements}

We would like to appreciate the people of Gyalshing Sub-Division for their active support during the fieldwork. We would also like to thank Mr. Bhim Tsong, Mr. Aitaman Subba and Lucky Doma Bhutia at Darap village for their kind co-operation during the research. Our sincere gratitude to the Deputy Director of Department of Economics, Statistics, Monitoring and Evaluation (DESME) at Tikjuk in West Sikkim for his assistance. Above all, we would like to express our heartfelt gratitude to the reviewers for their valuable suggestions.

\section{About the Authors}

Dr. Namita Chakma's research interest covers Geo-Environmental issues.

Ms. Sushmita Chakraborty completed her M.A. in Geography from The University of Burdwan, West Bengal. Presently, she is pursuing her PhD in the same department. 